\title{
PENGARUH BIMBINGAN RELAKSASI SPIRITUAL TERHADAP KECEMASAN PADA PASIEN PRE OPERASI DI RUANG SUNAN DRAJAT RSI SAKINAH KABUPATEN MOJOKERTO
}

\author{
Anik Supriani ${ }^{1 *}$, Edy Siswantoro ${ }^{1}$, Happy Rina Mardiana ${ }^{1}$, Nanik Nur Rosyidah ${ }^{1}$, \\ Moch Ulil Abshor ${ }^{1}$ \\ ${ }^{1}$ STIKES Dian Husada Mojokerto \\ *Correspondence: \\ Anik Supriani \\ Email: aniksupriani76@gmail.com
}

\begin{abstract}
Background: Tindakan operasi dan trauma bedah yang direncanakan dapat menimbulkan respon kecemasan pada responden. Kecemasan ini ditunjukan melalui gejala-gejala fisiologi, emosional dan kognitif. Salah satu psikoterapi untyk mengatasi kecemasan adalah dengan pendekatan spiritual keagamaan yaitu melalui bimbingan doa.

Purpose: Penelitian ini bertujuan untuk mengetahui pengaruh bimbingan relaksasi terhadap tingkat kecemasan pasien pre operasi.

Method: Desain penelitian yang digunakan adalah pre-experimental design dengan pendekatan one group pretest-posttest design. Sampel dipilih menggunakan metode conveince (accidental) sampling sebanyak 20 responden yaitu pasien pre operasi fraktur extremitas bawah, pada bulan februari 2017. Data penelitian ini diambil dengan menggunakan kuesioner. Variabel yang diukur dalam penelitian ini adalah tingkat kecemasan pada pasien pre operasi. Pengukuran tingkat kecemasan menggunakan skala kecemasan Hamilton Anxietas Rating Scale (HARS). Setelah ditabulasi data yang ada dianalisis dengan menggunakan uji statistic Wilcoxon signed ranks test dengan tingkat kemaknaan ( $\mathrm{p}<0,05)$. Kepada responden diberikan bimbingan doa sebanyak dua kali yaitu 1-2 jam operasi.

Results: Hasil penelitian menunjukan tingkat kecemasan sebelum intervensi diperoleh hasil tidak ada responden yang tidak cemas, kecemasan sedang 6 responden (30\%), sedangkan 14 responden $(70 \%)$ mengalami kecemasan berat. Sedangkan tingkat kecemasan responden sesudah intervensi menunjukan 6 orang (30\%) mengalami kecemasan sedang, 14 responden (70\%) mengalami kecemasan ringan. Dan tidak ada responden yang mengalami kecemasan berat. Hasil ini didapatkan nilai $\mathrm{p}=0,000$ pada tingkat $\mathrm{p} \leq 0,05(\leq 0,05)$. Bila dibandingkan dengan tingkat kemaknaan yaitu $0,000 \leq 0,05$, berarti Ho ditolak, H1 diterima Secara statistika berarti ada pengaruh yang signifikan dari intervensi yang diberikan.

Conclusion: Berdasarkan hasil penelitian ini maka perlu adanya pendekatan spiritual sebagai psikoterapi dalam mengatasi kecemasan pasien pre operasi.
\end{abstract}

Key words: relaksasi, spiritual, kecemasan, pre operasi

\section{PENDAHULUAN}

Keperawatan praoperatif dimulai ketika keputusan untuk intervensi bedah dibuat dan berakhir ketika pasien dikirim ke meja operasi (Brunner \& Suddarth, 2013). Pada pasien pre operasi tidak jarang memiliki perasaan terganggu yang muncul akibat pelayan kesehatan yang hanya melakukan pemantauan TTV serta kurangnya komunikasi antara pelayan kesehatan dengan pasien pre operasi (Smeltzer \& Bare, 2002). Seharusnya pasien yang akan melakukan operasi harus memiliki kesiapan mental maupun emosional untuk 
kelancaran operasi. Lancar atau tidak proses operasi nanti pasti ada rasa nyeri saat operasi. Spiritualitas memberikan pengertian keterhubungan interpersonal (dengan diri sendiri), interpersonal (dengan orang lain) dan transpersonal (dengan yang tidak terlihat, Tuhan atau yang tertinggi) (Minner-William, 2006). Pelayan kesehatan di RSI Sakinah Kota Mojokerto belum menerapkan bimbingan relaksasi spiritual untuk menanggulangi rasa cemas pada pasien pre operasi. Hasil wawancara dengan kepala ruangan sunan drajat RSI Sakinah Kota Mojokerto bahwasanya banyak pasien pre operasi yang mengalami kecemasan serta kegelisahan dalam menghadapi operasi. Dan hal tersebut diatas dapat diketahui bahwa masih banyak pasien pre operasi yang mengalami kecemasan serta kurangnya bimbingan spiritual.

Adapun hasil data dari World Health Organization (WHO) pada tahun 2007, Amerika Serikat menganalisis data dari 35,539 klien bedah dirawat di unit 2,473 klien (7\%) mengalami kecemasan. Kemudian hasil dari penelitian di Indonesia pada tahun 2013 hampir 57,5\% pasien mengalami kecemasan pada pre operasi. Hasil data yang ada di RSI Sakinah Kota Mojokerto pada bulan Januari-Agustus (2016) terdapat 187 orang mengalami fraktur extremitas anggota gerak. Dan berdasarkan observasi pada tanggal 22 november 2016 terdapat 3 pasien dari 5 pasien mengalami kecemasan sebelum masuk ruang operasi

Ketidaktahuan tentang operasi dan dampak yang ditimbulkan setelah operasi merupakan salah satu penyebab terjadinya kecemasan pada pasien pre operasi dalam menghadapi operasi. Kecemasan yang dialami berpengaruh terhadap jalannya operasi. Kecemasan pada pasien pre operasi akan muncul seperti mudah marah, tersinggung, gelisah, lesu, tidak mampu memusatkan perhatian, dan ragu-ragu. Kecemasan atau ansietas pasien pre operasi yang menghadapi proses operasi salah satu masalah gangguan emosional yang sering ditemui dan menimbulkan dampak psikologis cukup serius. Dampak dari kecemasan dapat menimbulkan rasa sakit meliputi peningkatan frekuensi nadi dan respirasi, pergeseran tekanan darah dan suhu, kulit dingin dan lembab. Kegelisahan dan kecemasan menimbulkan ketegangan, menghadapi relaksasi tubuh, menyebabkan keletihan atau bahkan mempengaruhi keadaan pasien sendiri, kondisi tersebut yang mengakibatkan otot tubuh menegang, terutama otot-otot ikut menjadi kaku dan keras sehingga sulit mengembang. Tidak hanya itu, emosi yang tidak stabil dapat membuat rasa sakit meningkat. Menjelang operasi, pasien membutuhkan ketenangan agar proses operasi menjadi lancar tanpa hambatan. Semakin pasien tenang menghadapi tindakan operasi maka operasi akan berjalan semakin lancar.

Menjelang operasi, pasien pre operasi membutuhkan ketenangan agar proses operasi menjadi lancar tanpa hambatan. Semakin pasien tenang menghadapi operasi maka operasi akan berjalan semakin lancar. Upaya untuk menurunkan tingkat kecemasan pada pasien pre operasi adalah dengan meningkatkan mutu pelayanan kesehatan terutama pemberian pelayanan pada aspek spiritual. Hal ini bisa dilakukan dengan kerja sama antara tenaga pelayan kesehatan, pasien dan kelurga pasien dengan cara memberikan pendekatan secara keagamaan, memberikan panduan pelaksanaan doa dan memberikan pengetahuan tentang kedahsyatan manfaat dari terapi spiritual. Berdasarkan latar 
belakang diatas penulis ingin mengetahui pengaruh teknik spiritual terhadap kecemasan pada pasien pre operasi di Ruangan Sunan Drajat RSI Sakinah Kota Mojokerto.

\section{METODE DAN BAHAN}

Desain penelitan yang digunakan dalam penelitian ini adalah pre eksperimental desain yaitu desain yang bertujuan untuk mengungkapkan kemungkinan adanya pengaruh bimbingan relaksasi spiritual terhadap tingkat kecemasan pada pasien pre operasi di Ruang Sunan Drajat RSI Sakinah Kota Mojokerto, dengan rancangan penelitian menggunakan pendekatan one group pretest-posttest desain.

Populasi dalam penelitian ini adalah semua pasien yang akan dilakukan operasi berencana di Ruang Sunan Drajat RSI Sakinah Kota Mojokerto dengan tingkat kecemasan ringan-besar. Pasien dengan operasi yang bersifat mayor, (beresiko besar dan dengan anastesi general atau spinal) dan bersifat elective (berencana).

Adapun langkah-langkah dalam pengumpulan data atau prosedur penelitian adalah sebagai berikut :

1) Mendekati calon responden

2) Menjelaskan tentang tujuan penelitian

3) Apabila setuju minta ttd kepada responden

(1)Pre test

1. Melakukan seleksi calon responden, kemudian melakukan pendekatan pada calon responden, menjelaskan tentang maksud dan tujuan penelitian serta jaminan kerahasiaan atas data yang diberikan, selanjutnya memberikan informed consent atau surat persetujuan setelah diberikan penjelasan kepada responden yang bersedia untuk diteliti.

2. Melakukan kontrak waktu untuk pengisian kuisioner beserta pelaksanaan teknik relaksasi spiritual

3. Memberikan kuisioner pre test kepada responden kemudian meminta responden untuk mengisinya sesuai kondisi klien saat itu, kemudian peneliti mengobservasi sikap responden dan mengisi ceklist waktu pengisian kuisioner antara 20-30 menit.

4. Menjelaskan prosedur bimbingan relaksasi spiritual, kemudian membimbing pelaksanaan intervensi bimbingan relaksasi spiritual waktu bimbingan antara 5-10 menit

(2)Intervensi

1. Memotivasi responden untuk berdoa.

2. Membangkitkan kesadaran klien bahwa manusia itu lemah dan membutuhkan Allah, dengan menjelaskan dan mencontohkan sifat pengasih dan penyayang Allah melalui fungsi tubuh/fisik yang Allah berikan, semisal fungsi jantung dan paru-paru yang diatur oleh Allah, sementara manusia tidak mampu mengendalikannya.

3. Menumbuhkan keikhlasan atas penyakit yang dideririta.

4. Menjelaskan dan mengajak klien untuk menyadari kebesaran Allah melalui penciptaan Allah semisal berapa biaya oksigen yang kita hirup sepanjang hidup bila dihitung dalam bentuk uang.

5. Menyadarkan klien bahwa operasi dan terapi merupakan suatu bentuk ikhtiar manusia.

6. Meminta klien mengangkat tangan bila mampu, posisi klien senyaman mungkin, meminta klien mengikuti doa dalam hati dan mengucapkan "Basmallah, Al-Fatihah, AlMuhaiminu"

7. Membaca doa dengan suara pelan dan perlahan beserta artinya.

8. Menganjurkan klien tetap rileks

9. Menganjurkan klien untuk pasrah dan tawakal serta yakin Allah akan menjawab doa.

(3) Post test

1. 1 jam sebelum pelaksanaan operasi, dilakukan intervensi teknik relaksasi spiritual yang kedua

2. Setelah intervensi selesai, dilakukan kembali pengukuran tingkat kecemasan klien dengan kuesioner/alat ukur yang sama. 
3. Kuisioner dan hasil observasi dicocokan kemudian dibuat kategori tingkat kecemasan pasien baik pre intervensi maupun post intervensi.

Pada kegiatan ini penelitian data dengan memberikan skor pada pertanyaan yang berkaitan dengan kecemasan responden. Pada kecemasan terdapat 13 kelompok pertanyaan kuisioner dan 1 Observasi, masing-masing kelompok gejala penilaian antara $0-4$

Nilai $0=$ Tidak ada gejala/keluhan

Nilai 1 = Gejala ringan (satu gejala dari pilihan yang ada)

Nilai $2=$ Gejala sedang (separuh dari gejala yang ada)

Nilai $3=$ Gejala berat (lebih dari separuh gejala yang ada)

Nilai 4 = Gejala sangat berat (semua gejala ada)

Hasil penilaian

1) $<14=$ Tidak Ada Kecemasan.

2) $14-20=$ Kecemasan Ringan.

3) $21-27=$ Kecemasan Sedang.

4) $28-41=$ Kecemasan Berat.

5) $42-56=$ Kecemasan Berat Sekali Analisis data untuk mengidentifikasi pengaruh spiritual terhadap penurunan tingkat kecemasan pada pasien pre operasi mengunakan uji Wilcoxon signed rank test. Apabila $\rho$ value $\alpha<0,05$ maka $\mathrm{H}_{1}$ diterima yang artinya ada pengaruh spiritual dalam penurunan tingkat kecemasan pada pasien pre operasi.

\section{HASIL PENELITIAN \\ Data Umum}

\section{Karakteristik Responden Berdasarkan Jenis Kelamin}

Tabel 1. Distribusi Frekuensi Responden Berdasarkan Jenis Kelamindi Ruang Sunan Drajat RSI Sakinah Kota Mojokerto pada bulan April 2017.

\begin{tabular}{|l|l|l|l|}
\hline No & $\begin{array}{l}\text { Jenis Kelamin } \\
\text { Responden }\end{array}$ & Jumlah & $\begin{array}{l}\text { Presentase } \\
(\%)\end{array}$ \\
\hline 1 & Laki - laki & 8 & $40 \%$ \\
\hline 2 & Perempuan & 12 & $60 \%$ \\
\hline \multicolumn{2}{|l|}{ Total } & 20 & $100 \%$ \\
\hline
\end{tabular}

Sumber: kuisioner April 2017

Berdasarkan tabel 1 diatas menunjukan sebagian besar Jenis Kelamin perempuan 12 responden dengan prsentase $(60 \%)$.

\section{Karakteristik Responden Berdasarkan Umur}

Tabel 2. Distribusi Frekuensi Responden Berdasarkan Umur di Ruang Sunan Drajat RSI Sakinah Kota Mojokerto pada bulan April 2017.

\begin{tabular}{|l|l|l|l|}
\hline No & Umur Responden & Jumlah & $\begin{array}{l}\text { Presentase } \\
(\%)\end{array}$ \\
\hline 1 & $17-25$ Tahun & 9 & $45 \%$ \\
\hline 2 & $26-55$ Tahun & 6 & $30 \%$ \\
\hline 3 & $56-60$ Tahun & 5 & $25 \%$ \\
\hline \multicolumn{2}{|l|}{ Total } & 20 & $100 \%$ \\
\hline
\end{tabular}

Sumber: kuisioner April 2017

Berdasarkan tabel 2 diatas menunjukan sebagian besar umur responden 17 sampai 25 tahun dengan prosentase $(45 \%)$.

\section{Karakteristik Responden Berdasarkan Pendidikan}

Tabel 3. Distribusi Frekuensi Responden Berdasarkan Pendidikan di Ruang Sunan Drajat RSI Sakinah Kota Mojokerto pada bulan April 2017

\begin{tabular}{|l|l|l|l|}
\hline No & $\begin{array}{l}\text { Tingkat } \\
\text { Pendidikan }\end{array}$ & Jumlah & Presentase (\%) \\
\hline 1 & Tidak Sekolah & 0 & $0 \%$ \\
\hline 2 & SD & 2 & $10 \%$ \\
\hline 3 & SMP & 4 & $20 \%$ \\
\hline 4 & SMA & 12 & $60 \%$ \\
\hline 5 & Perguruan Tinggi & 2 & $10 \%$ \\
\hline \multicolumn{2}{|l|}{ Total } & 20 & $100 \%$ \\
\hline
\end{tabular}

Sumber: kuisioner April 2017

Berdasarkan tabel 3 diatas menunjukan sebagian besar berpendidikan SMA sebanyak 12 responden dengan prosentase $(60 \%)$ 


\section{Karakteristik Responden Berdasarkan Pekerjaan}

Tabel 4. Distribusi Frekuensi Responden Berdasarkan Pekerjaandi Ruang Sunan Drajat RSI Sakinah Kota Mojokerto pada bulan April 2017

\begin{tabular}{|l|l|l|l|}
\hline No & Kategori Pekerjaan & Jumlah & $\begin{array}{l}\text { Presentase } \\
(\%)\end{array}$ \\
\hline 1 & Wiraswasta & 3 & $15 \%$ \\
\hline 2 & Swasta & 4 & $20 \%$ \\
\hline 3 & PNS & 3 & $15 \%$ \\
\hline 4 & Pensiun & 1 & $5 \%$ \\
\hline 5 & Buruh/Tani & 2 & $10 \%$ \\
\hline 6 & Lain - lain & 7 & $35 \%$ \\
\hline \multicolumn{2}{|l}{ Total } & 20 & $100 \%$ \\
\hline
\end{tabular}

Sumber: kuisioner April 2017

Berdasarkan tabel 4 diatas jenis pekerjaan responden terbanyak adalah sebagai ibu rumah tangga, pelajar atau mahasiswa, yakni sejumlah 7 orang (35\%) yang dimasukan kedalam kategori pekerjaan lain-lain.

\section{Karakteristik Responden Berdasarkan Riwayat Operasi}

Tabel 5. Distribusi Frekuensi Responden Berdasarkan Riwayat Operasi di Ruang Sunan Drajat RSI Sakinah Kota Mojokerto pada bulan April 2017

\begin{tabular}{|l|l|l|l|}
\hline No & $\begin{array}{l}\text { Jenis Kelamin } \\
\text { Responden }\end{array}$ & Jumlah & $\begin{array}{l}\text { Presentase } \\
(\%)\end{array}$ \\
\hline 1 & Pertama kali & 15 & $75 \%$ \\
\hline 2 & $>1$ & 5 & $25 \%$ \\
\hline \multicolumn{2}{|l|}{ Total } & 20 & $100 \%$ \\
\hline
\end{tabular}

Sumber: kuisioner April 2017

Berdasarkan tabel 5 diatas menunjukan sebagian besar Riwayat Operasi pertama kali sebanyak 15 responden $(75 \%)$.

\section{Data Khusus}

Tingkat kecemasan pasien pre operasi sebelum bimbingan relaksasi spiritual

Tabel 6. Tingkat Kecemasan Responden Sebelum Teknik Relaksasi Spiritual.

\begin{tabular}{|l|l|l|l|}
\hline No & $\begin{array}{l}\text { Tingkat } \\
\text { Kecemasan }\end{array}$ & $\begin{array}{l}\text { Jumlah } \\
\text { Responden }\end{array}$ & Presentase (\%) \\
\hline 1 & $\begin{array}{l}\text { Tidak ada } \\
\text { kecemasan }\end{array}$ & 0 & $0 \%$ \\
\hline 2 & $\begin{array}{l}\text { Kecemasan } \\
\text { ringan }\end{array}$ & 0 & $0 \%$ \\
\hline 3 & $\begin{array}{l}\text { Kecemasan } \\
\text { sedang }\end{array}$ & 6 & $30 \%$ \\
\hline 4 & $\begin{array}{l}\text { Kecemasan } \\
\text { berat }\end{array}$ & 14 & $70 \%$ \\
\hline 5 & $\begin{array}{l}\text { Kecemasan } \\
\text { berat sekali }\end{array}$ & 0 & $0 \%$ \\
\hline & & 20 & $100 \%$ \\
\hline
\end{tabular}

Sumber : Data primer yang dioloah

Dari tabel 6 dapat diketahui bahwa pada dasarnya semua responden mengalami kecemasan, akan tetapi tingkat kecemasan yang bervariasi. Tingkat kecemasan sebagian besar dari data tersebut adalah pada tingkat kecemasan berat, yaitu sebanyak 14 orang (70\%).

\section{Tingkat kecemasan pasien pre operasi sesudah bimbingan relaksasi spiritual}

Tabel 7. Tingkat Kecemasan Responden Sesudah Teknik Relaksasi Spiritual.

\begin{tabular}{|c|l|l|l|}
\hline No & $\begin{array}{l}\text { Tingkat } \\
\text { Kecemasan }\end{array}$ & $\begin{array}{l}\text { Jumlah } \\
\text { Responden }\end{array}$ & $\begin{array}{l}\text { Presentase } \\
(\%)\end{array}$ \\
\hline 1 & $\begin{array}{l}\text { Tidak ada } \\
\text { kecemasan }\end{array}$ & 0 & $0 \%$ \\
\hline 2 & Kecemasan ringan & 14 & $70 \%$ \\
\hline 3 & Kecemasan sedang & 6 & $30 \%$ \\
\hline 4 & Kecemasan berat & 0 & $0 \%$ \\
\hline 5 & $\begin{array}{l}\text { Kecemasan berat } \\
\text { sekali }\end{array}$ & 0 & $0 \%$ \\
\hline & 20 & $100 \%$ \\
\hline
\end{tabular}

Sumber : Data primer yang diolah

Dari tabel 7 dapat diketahui bahwa distributor responden sesudah pemberian terapi spiritual menunjukan bahwa sebagian besar tingkat kecemasan yang dialami adalah kecemasan ringan yakni sebanyak 14 orang $(70 \%)$. 


\section{PEMBAHASAN}

\section{Tingkat kecemasan pasien pre operasi sebelum bimbingan relaksasi spiritual}

Berdasarkan tabel 4.7 distribusi tingkat kecemasan responden pre operasi sebelum diberikan teknik relaksasi spiritual diketahui bahwa 6 responden mengalami kecemasan sedang (30\%), sedangkan 14 responden $(70 \%)$ mengalami kecemasan berat.Data diatas menunjukan bahwa secara umum keseluruhan responden mengalami kecemasan, namun dengan tingkat bervariasi.

Kecemasan adalah ketegangan, rasa tidak aman dan kekhawatiran yang timbul karena dirasakan terjadi sesuatu yang tidak menyenangkan tetapi sumbernya sebagian besar tidak diketahui dan berasal dari dalam (Stuart \& Sundeen, 1998). Kecemasan adalah perasaan yang dialami ketika seseorang terlalu mengkhawatirkan kemungkinan peristiwa yang menakutkan yang terjadi dimasa depan yang tidak bisa dikendalikan dan jika itu terjadi akan dinilai sebagai "mengerikan" (Sivalitar, 2003).

Sebelum diberikan Bimbingan relaksasi spiritual, sebanyak 20 responden mengalami peningkatan tingkat kecemasan dengan berbagai variasi tingkat kecemasan. Variasi tingkat kecemasan yang dirasakan oleh responden dimungkinkan karena perbedaan kemampuan individu dalam merespon kecemasan, hal ini dapat dihubungkan dengan karakteristik yang dimiliki oleh setiap responden.

Variasi tingkat kecemasan yang dialami oleh pasien pre operasi dimungkinkan terjadi karena pengaruh beberapa faktor anatara lain : usia, jenis kelamin, pengalaman, keyakinan dan komitmen spiritual.

\section{Usia}

Berdasarkan tabel 4.2 diatas menunjukan sebagian besar umur responden 17 sampai 25 tahun sebanyak 9 dengan prosentase (45\%). Dari data yang di dapatkan, tingkat kecemasan berat dialami oleh 9 orang dengan usia muda, diantaranya 6orang kecemasan berat dan 3 orang kecemasan sedang. Menurut Nursalam (2001) umur adalah usia individu yang terhitung mulai saat dilahirkan sampai saat berulang tahun, semakin cukup umur tingkat kematangan dan kekuatan seseorang akan lebih matang dalam berfikir dan bekerja. Seseorang yang mempunyai usia lebih muda ternyata lebih muda mengalami gangguan kecemasan dari pada seseorang yang lebih tua, tetapi ada juga yang berpendapat sebaliknya (Stuart, 2006).

Bahwa pasien-pasien lanjut usia dan religius (banyak berdoa dan berdzikir) kurang mengalami rasa ketakutan atau kecemasan terhadap operasi yang akan dijalaninya. Mereka tidak merasa takut mati serta tidak menunda-nunda jadwal operasi. Temuan ini berbeda dengan pasien-pasien yang muda usia dan kurang religius, dalam menghadapi operasi, mereka mengalami ketakutan, kecemasan dan takut mati serta seringkali menundanunda jadwal operasi.

\section{Jenis Kelamin}

Berdasarkan tabel 4.1 diatas menunjukan dari setengah responden $(60 \%)$ adalah berjenis kelamin perempuan yaitu sejumlah 12 orang. Data yang diperoleh juga diketahui bahwa dari 8 orang $(40 \%)$ responden yang mengalami kecemasan ringan berjenis kelamin lakilaki, adapun dari 6 responden (30\%) yang mengalami kecemasan sedang adalah 4 respon berjenis kelamin laki-laki dan 2 responden berjenis kelamin perempuan, sedangkan responden yang mengalami kecemasan berat sebanyak 14 orang $(70 \%)$, dan 8 orang diantaranya adalah perempuan sementara 6 orang responden laki-laki mengalami kecemasan berat.

menggambarkan bahwa responden perempuan cenderung mengalami tingkat kecemasan yang lebih tinggi dan jumlahnya lebih banyak dibandingkan laki-laki, hal ini sesuai pendapat isaacs (2005) 
Gangguan ansietas umum menyerang perempuan dua kali lebih banyak dari pada laki-laki. Karena perbedaan kemampuan optimal pada otak pria dan wanita ini dalam menghadapi kecemasan, kemampuan memprediksi dan merasakan sesuatu. Selain itu juga hormon juga memainkan peran atas perasaan lebih cemas pada wanita disebutkan juga karena adanya kolerasi fluktuasi hormon dan sensitivitas emosional. Dengan hormonhormon ini wanita lebih memicu kecemasan dari pada laki-laki.

\section{Pengalaman}

Pada penelitian ini lebih dari setengah responden (75\%) mempunyai riwayat operasi pertama kali sebanyak 15 responden.

Trauma bedah yang direncanakan akan menimbulkan respon psikologis dan fisiologis pada klien. Respon ini tergantung pada individu, pengalaman masa lalu yang unik, pola koping, kekuatan dan keterbatasan individu Carpenito (2000). Individu yang mempunyai model kemampuan pengalaman menghadapi akan cenderung lebih menganggap stress yang berat pun sebagian masalah yang bisa di selesaikan (Isaacs, 2005)

Pengalaman operasi biasanya merupakan suatu pengalaman besar bagi seseorang, dan merupakan pengalaman yang tidak akan dapat dilupakan seseorang terkadang menganggap semua operasi sama besarnya, dari sama menakutkannya. Ketakutan pasien yang akan dilakukan tindakan operasi terutama terhadap kematian, luka dan nyeri. Bagi klien yang sudah pernah mengalami operasi, pengalaman operasi sebelumnya dapat dijadikan gambaran dan merupakan suatu bekal untuk menghadapi operasi berikutnya.

\section{Pendidikan dan Sosial Ekonomi}

Pada tingkat pendidikan, setengah dari jumlah responden $(60 \%)$ mempunyai pendidikan SMA yaitu sejumlah 12 orang. Adapun berdasarkan pekerjaan responden sebagian besar responden dikategorikan memiliki pekerjaan lain-lain sejumlah 7 orang $(35 \%)$, dengan perincian : ibu rumah tangga 4 orang, mahasiswa 2 orang dan pelajar 1 orang.

Tingkat pendidikan dan status ekonomi yang rendah akan menyebabkan orang tersebut mudah mengalami kecemasan. tingkat pendidikan seseorang atau individu akan berpengaruh terhadap kemampuan berfikir, semakin tinggi tingkat pendidikan akan semakin mudah berfikir rasional dan menangkap informasi baru termasuk dalam menguraikan masalah yang baru (Isaacs, 2005)

Selain itu kecemasan yang dialami oleh orang yang sosial ekonominya rendah umumnya lebih cenderung kepada kecemasan karena ketidak mampuan finansial dalam pembiayaan pengobatan, dibandingkan kecemasan menghadapi operasi itu sendiri. Terkadang orang yang memiliki kepasrahan, ketaatan dan ketundukan yang tinggi, ia menyerahkan semuanya kepada takdir dan kehendak Allah atas dirinya termasuk pembiayaan pengobatan, karena ia percaya Allah selalu menolongnya yang penting ia berikhtiar semaksimal mungkin. Jadi bukan mustahil orang ini akan lebih tenang menghadapi operasi, penyakit, bahkan kematian sekalipun.

\section{Tingkat kecemasan pasien pre operasi sesudah bimbingan teknik relaksasi spiritual}

Data Tabel 4.7 diketahui bahwa distribusi responden sesudah pemberian teknik relaksasi spiritual menunjukan 6 orang $(30 \%)$ responden dari 20 responden yang diteliti, mengalami kecemasan sedang, sedangkan tingkat kecemasan terbanyak yang dialami adalah kecemasan ringan yakni sebanyak 14 orang $(70 \%)$. Dan tidak ada responden yang mengalami kecemasan berat.

Menyebutkan bahwa jenis bimbingan spiritual dapat berupa bimbingan doa, solat, dzikir, dan membaca Al'Quran. Ketika berdoa akan 
menimbulkan rasa percaya diri, rasa optimisme (harapan kesembuhan), mendatangkan ketenangan, damai dan merasakan kehadiran Tuhan Yang Maha Esa sehingga mengakibatkan tubuh meresponden dengan mensekresikan beberapa hormone tertentu (Taufik, 2006)

Disaat itu pasien merasa putus asa dan pada kondisi yang terhimpit serta mengalami kecemasan berat tetapi setelah dilakukan teknik relaksasi spiritual ia berdoa lebih bersungguh-sungguh dan dengan merendahkan diri di hadapan Allah serta ikhlas dan berserah diri dalam berdoa. Dengan sikap mental dan pasrah inilah yang akan melatar belakangi penurunan tingkat kecemasan bagi pasien

\section{Analisa pengaruh bimbingan relaksasi spiritual terhadap kecemasan pada pasien pre operasi sebelum dan sesudah teknik relaksasi spiritual.}

Daril hasil uji Wilcoxon Sign Rank Test, didapatkan nilai $\mathrm{p}=0,000$ pada tingkat $p \leq 0,05(\leq 0,05)$. Bila dibandingkan dengan tingkat kemaknaan yaitu $0,000 \leq$ 0,05 , berarti Secara statistika berarti ada pengaruh yang signifikan dari intervensi yang diberikan.

Kecemasan dimanefestasikan dalam tingkat yang berbeda dari mulai ringan sampai berat. Manifestasi kecemasan yang terjadi tergantung pada kematangan pribadi, pemahaman dalam menghadapi ketegangan, harga diri dan mekanisme koping Stuart \& Sundeen (1998). Bacaan ayat suci Al'Quran dan bacaan doa yang menenangkan dapat membantu mengurangi kecemasan dan stress dengan menurunkan hormonehormon yang berhubungan dengan stress dan cemas (Ortiz, 2002)

Sebelum dilakukan tindakan bimbingan relaksasi spiritual responden mengalami kecemasan, kekhawatiran dan bimbang sebelum dilakukan tindakan operasi. Begitu pun proses pada kecemasan yaitu stimulus dikirim ke hipotalamus, menstimulus sistem saraf otonom dan neurotransmitter, otonom bersifat hipersensitif dan mempunyai reaksi berlebih terhadap menstimulus simpatik dan responden mengalami kecemasan. Dalam mengontrol kecemasan responden tersebut dapat diupayakan dengan melakukan tindakan bimbingan relaksasi spiritual dengan cara membaca Basmallah, Al-fatihah dan Al-Muhaiminu karena manfaat yang dapat diperoleh dari pendekatan spiritual adalah selalu optimis dalam menghadapi tindakan operasi sehingga responden tetap tenang dan kontruktif. Data diatas menunjukan bahwa teknik relaksasi spiritual yang diberikan dapat menurunkan tingkat kecemasan pada responden yang akan dilakukan tindakan operasi.

\section{SIMPULAN}

Tingkat kecemasan pasien sebelum pemberian bimbingan relaksasi spiritual diperoleh hasil bahwa tidak ada responden yang tidak cemas, kecemasan berat dialami 14 responden $(70 \%)$. Tingkat kecemasan pasien sesudah pemberian bimbingan relaksasi spiritual diperoleh hasil mengalami kecemasan ringan 14 responden (70\%). Dari hasil penelitian yang dilakukan didapatkan adanya pengaruh teknik bimbingan relaksasi spiritual terhadap penurunan kecemasan pada pasien pre operasi $(\mathrm{p}=0,000)$.

\section{SARAN}

Diharapkan bimbingan relaksasi spiritual tersebut dapat dibuat Satuan Operasional Prosedur (SOP) dan dapat digunakan sebagai salah satu alternatif psikoterapi dan pengobatan non farmakologi pada pasien dengan ansietas pada umumnya dan pasien pre operasi khususnya. 


\section{DAFTAR PUSTAKA}

1. Alimul. HA 2003. Riset Keperawatan dan Teknik Penulisan Ilmiah. Salemba Medika. Jakarta.

2. Al-jammal. 1997. Penyakit-penyakit Hati. Pustaka Hidayah. Bandung.

3. Asmadi. 2008. Teknik Prosuderal Keperawatan Konsep dan Aplikasi Kebutuhan Dasar Klien. Salemba Medika. Jakarta.

4. Asyur. 1988. Berbakti Kepada Ibu Bapak. Gema Insani Pres. Jakarta.

5. Brunner \& Suddarth. 2013. Keperawatan Medikal-Bedah. EGC. Jakarta.

6. Carpenito. 2000. Rencana Asuhan dan Dokumentas Keperawatan. EGC. Jakarta.

7. Carr. 1999. Toward A New Recommended Dietary Allowance for Vitamin C Bassed On Antioxidan And Health Effect In hummans." The American Journal of Clinical Nurtrition.

8. Djakfar. 1995. Kompilasi Hukum Kewarisan Islam. PT Dunia Pustaka Jaya. Jakarta.

9. Guyton. 1995. Fisiologi Manusia Dan Mekanisme Penyakit. EGC. Jakarta.

10. Hafidh Amdjad. 1999. Keistimewaan \& Peranan Al Asmaul Husna di Zaman Modern. Yayasan Majelis Khidmah Al Asmaul Husna. Semarang.

11. Hanif Ida, Mahadun Hanifuddin. 2006. aL-ASMA aL-HUSNA. CV. Percetakan Fajar. Bandung.

12. Hawari. 2001. Manajemen Stres Cemas dan Depresi. Gaya Baru. Jakarta

13. Ja'far Subhani. 1997. Tauhid dan Syirik. Mizan. Bandung.

14. Kaplan. 1997. Sinopsis Psikitiatri Jilid 1. Binarupa Aksara. Jakarta.

15. Kawakib Nurul. 2012. Dahsyatnya Terapi Spiritual. Pustaka Al Ma'ruf. Lamongan.

16. Kawakib Nurul. 2005. Do'a Dalam Pengobatan. Radar Jember.
17. Kawakib Nurul. 2004. Legalitas Terapi Medis dan Bedah. Radar Jember.

18. Kozier dan B. Erb. 1998. Fundamental Of Nursing. CV Mosby Company. Toronto.

19. Kozier, Erb, Blasis, and Wilkinson. 1995. Fundamental Of Nursing, Concept Proses And Practise. Adison Wesley Publishing Company. California.

20. Lestari Titik. 2015. Kumpulan Teori Untuk Kajian Pustaka Penelitian Kesehatan. Nuha Medika. Yogyakarta.

21. Long. 1996. Perawatan Medikal Bedah. Yayasan IAPK Pajajaran. Bandung.

22. Maryunani Anik. 2015. Asuhan Keperawatan Intra Operasi Di Kamar Bedah (Selama Pembedahan). CV. Trans Info Media. Jakarta.

23. Mubarak Iqbal, Indrawati Lilis, Susanto Joko. 2015. Buku Ajar Ilmu Keperawatan Dasar. Salemba Medika. Jakarta Selatan.

24. Najati. 2001. Jiwa Manusia dalam Sorotan Al'Quran. Cendikia. Jakarta.

25. Nasr SH. 2002. Islamic Spirituality Foundations. Mizan. Bandung

26. Purwanto Setiyo, 2007. Psikologi Islam Transpersonal dan Psikologi Kesehatan.

27. Safitri. 2006. Pengaruh Partisipasi dalam penyusunan Anggaran Terhadap Kepuasan Kerja dan Kinerja Karyawan. PT Merapi Utama. Yogyakarta.

28. Setiadi. 2007. Konsep Dan Penulisan Riset Keperawatan. Graha Ilmu. Yogyakarta.

29. Sholeh. 2010. Buku Ajar Neonatologi. IDAI. Jakarta

30. Smeltzer \& Bare. 2001. Keperawatan Medikal Bedah 2. EGC. Jakarta.

31. Stuart \& Sundeen. 1998. Buku Saku Keperawatan Jiwa. EGC. Jakarta.

32. Sugiyono. 2015. Metode Penelitian Pendidikan Pendekatan Kuantitatif, Kualitatif, dan $R \& D$. Alfabeta. Bandung. 
33. Syamsuhidayat. 1998. Buku Ajar Ilmu Bedah. EGC. Jakarta.

34. Wignjosoebroto. 1994. Dari Hukum Kolonial Ke Hukum Nasional. PT Raja Grafindo Pustaka. Jakarta.
35. Yani. A. 2008. Bunga Rampal Asuhan Keperawatan Jiwa, EGC, Jakarta 